\title{
Holdover Inoculum of Pseudomonas syringae pv. alisalensis from Broccoli Raab Causes Disease in Subsequent Plantings
}

\author{
N. A. Cintas, USDA, PWA, ARS, 1636 E. Alisal Ave., Salinas, CA 93905; S. T. Koike, University of California Co- \\ operative Extension, Salinas 93901; R. A. Bunch, D’Arrigo Bros. Co., Salinas, CA 93902; and C. T. Bull, USDA, \\ PWA, ARS, 1636 E. Alisal Ave., Salinas, CA 93905
}

\begin{abstract}
Cintas, N. A., Koike, S. T., Bunch, R. A., and Bull, C. T. 2006. Holdover inoculum of Pseudomonas syringae pv. alisalensis from broccoli raab causes disease in subsequent plantings. Plant Dis. 90:1077-1084.

Uniform plots of broccoli raab (Brassica rapa subsp. rapa) seedlings were inoculated with a rifampicin-resistant strain of Pseudomonas syringae pv. alisalensis, the causal agent of bacterial blight on crucifers, resulting in 100\% disease incidence in mature plants. Diseased plants were incorporated into the soil at maturity and smaller replicated plots were replanted at various times after incorporation. Rifampicin-resistant fluorescent pseudomonads with rep-PCR profiles identical to P. syringae pv. alisalensis were isolated from lesions on plants grown in soil into which the first diseased crop was incorporated. Disease incidence declined in mature plants as the length of time between incorporation of the first planting and seeding of the replanted plots increased. Bacterial population levels in soil decreased over time and bacteria were no longer detectable 3 weeks after incorporation of the diseased crop. In laboratory tests, population levels of $P$. syringae pv. alisalensis decreased in untreated soil but not in autoclaved soil. Greenhouse studies demonstrated a direct correlation between population levels of $P$. syringae pv. alisalensis applied to soil and disease incidence in seedlings. However, the decline in bacterial populations in field soils did not wholly account for the decline in disease incidence with subsequent plantings.
\end{abstract}

Additional keywords: crop rotation, fallow, myxobacteria

Broccoli raab (Brassica rapa subsp. rapa) is a gourmet vegetable with a slightly bitter taste used in Italian and Chinese cooking. Although it is a minor crop nationally, broccoli raab is an important crop for Monterey County, CA, and is grown on approximately 1,214 ha with a value of $\$ 12$ million (26). Approximately $90 \%$ of broccoli raab grown in the United

Corresponding author: C. T. Bull

E-mail: cbull@pw.ars.usda.gov

Current address of N. A. Cintas: Northern Virginia Community College, Alexandria Campus, 3001 North Beauregard Street, Alexandria, VA 223115097.

The mention of a trade name, proprietary product, or vendor does not constitute an endorsement, guarantee or warranty by the United States Department of Agriculture and does not imply its approval or the exclusion of these or other products that may be suitable.

* The $\boldsymbol{e}$-Xtra logo stands for "electronic extra" and indicates the HTML abstract available on-line contains supplemental figures not included in the print edition.

Accepted for publication 28 March 2006.

DOI: 10.1094/PD-90-1077

This article is in the public domain and not copyrightable. It may be freely reprinted with customary crediting of the source. The American Phytopathological Society, 2006.
States is grown in California, with production in Monterey County representing approximately $65 \%$ of the U.S. acreage.

Bacterial blight of broccoli raab is a relatively new and potentially devastating disease. The disease was first described in 1998, when commercial fields in the Salinas Valley were affected (24). Initial symptoms consist of small, water-soaked flecks on the lower foliage. These flecks expand and become surrounded by bright yellow borders, which eventually may coalesce and result in large necrotic areas. This disease is economically important because large necrotic areas may form on foliage, rendering the crop unmarketable. It continues to be a problem in commercial settings as well as in breeding trials on the central coast of California.

Initial studies showed that the pathogen was Pseudomonas syringae (24) but the pathovar was not identified. Because Pseudomonas syringae pv. maculicola causes bacterial spot on many crucifers, the causal agent of bacterial blight of broccoli raab could have been mistaken for this pathogen. However, the broccoli raab pathogen had a distinct colony morphology, and subsequent characterization revealed that the pathogen was significantly different from $P$. syringae pv. maculicola and other previously described crucifer pathogens. A novel pathovar, Pseudomonas syringae pv. alisalensis (12), was des- ignated for the pathogen causing bacterial blight of broccoli raab because the pathogen has a unique broad host range and repetitive sequence-based PCR (rep-PCR) fingerprint (12). Outbreaks of bacterial blight in commercial broccoli (Brassica oleracea subsp. botrytis) (23) and arugula (Eruca sativa) plantings were also caused by this pathogen $(5,6)$. Recently, it has been identified as the causal agent of bacterial blight of broccoli raab and arugula in New Jersey (6). P. syringae pv. alisalensis has a much broader experimental host range than does $P$. syringae pv. maculicola, including some monocots (California brome, Bromus carinatus; oat, Avena sativa; and common timothy, Phleum pratense), crucifers (cauliflower, Brassica oleracea subsp. botrytis; Brussels sprouts, Brassica oleracea subsp. gemmifera; asprobrock, Brassica oleracea var. botrytis $\times$ Brassica alboglabra; rape, Brassica napus; white mustard, Brassica hirta; and radish, Raphanus sativus), and tomato (Lycopersicon esculentum), many of which are important cash or cover crops for central coastal California $(7,11,12)$.

Little is known about the ecology and epidemiology of $P$. syringae pv. alisalensis in contrast to $P$. syringae pv. maculicola and other $P$. syringae pathovars. Various pathovars of $P$. syringae are seedborne in vegetable crops. They may also survive in the soil primarily in plant debris and can serve as a significant source of inoculum for disease in subsequent crops. For example, $P$. syringae pv. maculicola survives in debris in the soil for up to 2 months after incorporation (50), and holdover inoculum of $P$. syringae pv. tomato from previous plantings may result in disease in subsequent tomato plantings (20). However, the ability of the pathogens to survive in soil and/or debris and to serve as holdover inoculum differs depending on environmental conditions $(14,16,18,21,29,37)$, as well as race of particular pathovars of $P$. syringae (31). Additionally, $P$. syringae is a heterogeneous species, currently in the process of being split into at least eight species based on genomic relatedness (17). These species differ ecologically, and thus the importance of various inoculum sources may also differ. Because of the variation in the effect of holdover inoculum from soil and/or plant debris among $P$. syringae pathogens and the dearth of ecological information about $P$. syringae pv. 
alisalensis in particular, we cannot assume that holdover inoculum has a significant role in bacterial blight of crucifers.

P. syringae pv. alisalensis in soil or crop debris may have significant implications for disease management if surviving inoculum infects new plantings. This would be particularly important in the central coast region of California where mild weather allows a long growing season and multiple plantings on an individual field each year. Broccoli raab is commonly harvested 60 to 90 days after planting, which allows for two plantings each year. One production cycle can be followed by a second cycle, which may be planted quickly after the initial crop has been harvested. Because of this coastal California cropping system, it is necessary to understand the risk posed by inoculum from previous crops in order to implement successful management strategies.

The objectives of this research were to determine: (i) if the pathogen can survive in soil and serve as holdover inoculum for a subsequent crop; (ii) the influence of the length of fallow period after incorporation of diseased plants on disease development on subsequent crops; and (iii) the relationship between soil populations of $P$. syringae pv. alisalensis and disease incidence. Here we report data consistent with the

Table 1. Chemical and physical properties of two Salinas Valley sandy loam soils ${ }^{\mathrm{a}}$

\begin{tabular}{|c|c|c|}
\hline Property & Spence & Alisal \\
\hline $\mathrm{pH}$ & 7.1 & 7.9 \\
\hline Organic matter (\%) & 1.4 & 2.7 \\
\hline $\mathrm{K}(\mathrm{kg} / \mathrm{ha})$ & 425.9 & 112.1 \\
\hline $\mathrm{Ca}(\mathrm{kg} / \mathrm{ha})$ & 4483.4 & 897.7 \\
\hline $\mathrm{Mg}(\mathrm{kg} / \mathrm{ha})$ & 627.7 & 291.4 \\
\hline $\mathrm{Na}(\mathrm{kg} / \mathrm{ha})$ & 448.3 & 156.9 \\
\hline $\begin{array}{l}\text { Conductivity }(1: 5) \\
(\mu \mathrm{mhos} / \mathrm{cm})\end{array}$ & $\mathrm{NT}^{\mathrm{b}}$ & 180.0 \\
\hline Total soluble salts (ppm) & NT & 594.0 \\
\hline $\mathrm{NH}^{4+}(\mathrm{kg} / \mathrm{ha})$ & 20.2 & 11.2 \\
\hline $\mathrm{NO}^{3-}(\mathrm{kg} / \mathrm{ha})$ & 66.1 & 41.5 \\
\hline $\mathrm{Fe}(\mathrm{kg} / \mathrm{ha})$ & 41.5 & 14.6 \\
\hline $\mathrm{P}(\mathrm{kg} / \mathrm{ha})$ & 269.0 & 112.1 \\
\hline $\mathrm{Zn}(\mathrm{kg} / \mathrm{ha})$ & 1.8 & 3.6 \\
\hline Mn (kg/ha) & 12.3 & 13.5 \\
\hline $\mathrm{Cu}(\mathrm{kg} / \mathrm{ha})$ & 0.7 & 3.4 \\
\hline \multicolumn{3}{|l|}{ Textural class } \\
\hline Clay & $9.2 \%$ & $12.8 \%$ \\
\hline Silt & $20.0 \%$ & $29.0 \%$ \\
\hline Sand & $70.8 \%$ & $58.3 \%$ \\
\hline
\end{tabular}

hypothesis that holdover inoculum of $P$. syringae pv. alisalensis from previous crops causes disease in subsequent plantings, thus providing information to assist growers in adopting effective strategies for the control of bacterial blight of broccoli raab and reducing the risk of transmission of this disease to other economically important cruciferous crops. A preliminary report has been published (10).

\section{MATERIALS AND METHODS}

Bacterial strains and culture media. The bacteria used in these studies were stored at $-80^{\circ} \mathrm{C}$ in a solution of $50 \%$ glycerol and $50 \%$ nutrient broth (NB; Difco Laboratories, Detroit, MI). Bacteria were routinely cultured on nutrient agar (NA), tryptic soy agar (TSA; Difco Laboratories), and King's medium B (KB; 22). All chemicals were purchased from Sigma Corporation (St. Louis, MO) unless otherwise indicated.

The pathotype of $P$. syringae pv. alisalensis, strain BS 91 (ATCC BAA-566, CFBP 6866, ICMP 15200) (12) or a spontaneous rifampicin-resistant mutant, BS91r, was used in all experiments. The rifampicin-resistant mutant was generated on $\mathrm{KB}$ plates amended with rifampicin at $100 \mu \mathrm{g} / \mathrm{ml}$ using published methods (47). Generation times of the rifampicinresistant mutants and parental strains were compared in 0.10 strength tryptic soy broth (TSB) and NB. Only rifampicin-resistant mutants with generation times that did not differ from those of the parental strain were evaluated further. The rifampicinresistant mutants were analyzed for gram character as well as levan production, oxidase reaction, potato rot, arginine dihydrolase production, and tobacco hypersensitivity (LOPAT characters; 42). The repPCR patterns of the mutant were compared with those of wild-type strain as described below. Carbon utilization was compared using Biolog plates according to the manufacturer's recommendations (Biolog, Inc., Hayward, CA). Pathogenicity was evaluated on broccoli raab (cv. Spring) as previously described (12). A rifampicinresistant isolate, BS91r, which was identical to the pathotype in all tests, was selected for use in our experiments.

Establishment of field plots. To investigate whether bacteria from a previous crop can serve as inoculum for a new crop, we established identical field plots in 1999 and 2000 at two sites in Salinas, CA: field
C located at East Alisal Street and at Spence Road. Chemical and physical properties of the soils at these locations were analyzed by Soil Control Lab (Watsonville, CA) (Table 1).

The broccoli raab crop was grown using methods similar to commercial production practices. At each site, broccoli raab (cv. Dab) seeds were sown on 15 beds that were $2 \mathrm{~m}$ wide by $15.2 \mathrm{~m}$ long at a rate of 15 seeds per square foot using a tractor driven planter with seeder box attachments and bands created for broccoli raab seed. One trial was broadcast seeded by hand (Spence, 1999).

After plants emerged and two to four true leaves were fully expanded, they were inoculated with a water suspension of $P$. syringae pv. alisalensis. Bacterial cells were precipitated from an 18-h-old culture by centrifugation and resuspended in water. The cell suspension was adjusted spectrophotometrically to approximately $1 \times$ $10^{8} \mathrm{CFU} / \mathrm{ml}$. Bacteria were applied to plants with a hand-sprayer until runoff. Two identical experiments, one inoculated with strain BS91 and a second inoculated with BS91r, were established at each location. Approximately 20 liters of inoculum were applied to each experiment. Disease development was encouraged by periodic overhead irrigation during the 2 weeks after inoculation.

Effect of fallow on disease incidence in a subsequent planting. Fresh plant debris from fully mature diseased plants was incorporated by disking plants into the soil (1999) or by flail chopping the plants followed by incorporation by disking (2000). Dates of residue incorporation and replanting are given in Table 2. Beds were reshaped after incorporation. The plots were divided into six replications, each represented by one bed. Each bed was further divided into five subplots. Each subplot was $1 \mathrm{~m}$ wide by $1.5 \mathrm{~m}$ long with a minimum of $1.5 \mathrm{~m}$ of fallow land separating all plots. The first replant plots were planted approximately 1 week after incorporation of the diseased crop. Subsequent plots were sown at approximately 4-week intervals following planting of the first replant date. Seeds were sown in randomly selected subplots of each bed. Four rows of seed were sown on one-half of the 2-m beds with a hand pushed seeder. Approximately 2 weeks after replanting, plants in the middle two rows were thinned to a 7.6$\mathrm{cm}$ spacing. Replant plots were kept weed

Table 2. Timing of application of treatments

\begin{tabular}{|c|c|c|c|c|c|c|c|c|c|c|c|c|}
\hline \multirow[b]{2}{*}{ Year } & \multirow[b]{2}{*}{ Site } & \multirow{2}{*}{$\begin{array}{l}\text { Date of residue } \\
\text { incorporation }\end{array}$} & \multicolumn{5}{|c|}{ Interval to replanting (weeks) } & \multicolumn{5}{|c|}{ Interval to disease evaluation (weeks) } \\
\hline & & & $\mathbf{1}^{\mathrm{a}}$ & 2 & 3 & 4 & 5 & 1 & 2 & 3 & 4 & 5 \\
\hline 1999 & Alisal & $7 / 21 / 99$ & 1 & 5 & 9 & 13 & 17 & 12 & 15 & 21 & 27 & 32 \\
\hline 2000 & Alisal & $6 / 8 / 00$ & 1 & 5 & 9 & 15 & 19 & 8 & 12 & 16 & 21 & 24 \\
\hline 1999 & Spence & $7 / 2 / 99$ & 2 & 6 & 10 & 14 & 18 & 8 & 11 & 16 & 23 & 29 \\
\hline 2000 & Spence & $6 / 28 / 00$ & 1 & 5 & 11 & 15 & 19 & 8 & 12 & 19 & 25 & 31 \\
\hline
\end{tabular}

${ }^{a}$ Designation for replanting events. 
free by a preemergence application of herbicides Dacthal 75 WP and Prefar YEC at rates of $9.7 \mathrm{~kg} / \mathrm{ha}(8.0 \mathrm{lbs} / \mathrm{acre})$ and 9.4 liters/ha (4.0 qt/acre), respectively, followed by hand weeding of the plots when needed.

Plants were assessed for disease incidence at maturity, when broccoli raab florets were present on the main shoots. The percentage of plants that were diseased was calculated for the middle two rows of each replant plot after evaluating the number of symptomatic and asymptomatic plants. At least six symptomatic leaves were collected from each plot at each sampling time for immediate analysis of the bacteria present in lesions.

Disease incidence data from each replant experiment were analyzed by ANOVA for a randomized complete block (RCB) design using SAS (SAS Institute Inc., Cary, NC). Disease incidences, recorded as percentages, resulted in a binomial distribution. Prior to analysis, data were arcsine transformed resulting in a normal distribution of residuals. At each of the two locations each year, two independent RCB experiments were conducted, one inoculated with BS91r and one inoculated with BS91. Each experiment had six replications and five treatments. Another
ANOVA was performed by pooling each of the two RCB data sets from a single location, because the variances for the two experiments at each location were not significantly different. The analysis of the pooled data is presented (Fig. 1). Least significant difference analysis was performed as a mean separation analysis when ANOVA resulted in significant differences. Correlation and regression analysis of time of replanting versus disease incidence was also performed using SAS.

Presence of the pathogen in lesions on plants from replant plots. Bacteria were isolated from single lesions from at least six symptomatic leaves from each plot at each sampling time. An excised sample of approximately $3 \times 3 \mathrm{~mm}$ per lesion was surface-disinfested with bleach $(0.5 \%$ sodium hypochlorite) for $1 \mathrm{~min}$ followed by three rinses in sterile distilled water. The tissue was macerated in a drop of sterile distilled water. Aliquots of serial dilutions were spread onto the semiselective medium, KBBC (42) and KBBC amended with rifampicin $(100 \mu \mathrm{g} / \mathrm{ml})$ $(\mathrm{KBBCr})$. Plates were incubated at $27^{\circ} \mathrm{C}$ for at least 4 days prior to counting colonies. The numbers of fluorescent colonies that grew on rifampicin-amended and -nonamended media were compared. At least one rifampicin-resistant colony from each sample was compared with $P$. syringae pv. alisalensis using the PCR of repetitive bacterial sequences. PCR amplification of repetitive sequences was accomplished with the BOXA1R primer (5'-CTA-CGG-CAA-GGC-GAC-GCT-GACG-3'), synthesized by Operon Technologies, Inc. (Alameda, CA), that is designed to prime DNA synthesis from the BOXA subunit of the BOX element $(39,46)$. The PCR was carried out according to published methods using cells harvested directly from agar plates (39). It was carried out in an MJ Research DNA-Engine thermo-cycler with a heated lid in the "block" mode (MJ Research, Watertown, MA) with the use of $T a q$ polymerase (Perkin Elmer, Foster City, CA). Amplified DNA fragments were examined by agarose gel electrophoresis in $1.5 \%$ agarose gels in $0.5 \times$ Tris acetate EDTA buffer. Gels were stained with ethidium bromide, and DNA was photographed on a UV transilluminator with Polaroid type 55 film. Fingerprints generated from different strains were compared visually to DNA from BS91.

Survival of bacteria in the field. Culturable populations of $P$. syringae pv. alisalensis strain BS91r were monitored in the soil after incorporation of infested
A Alisal 1999

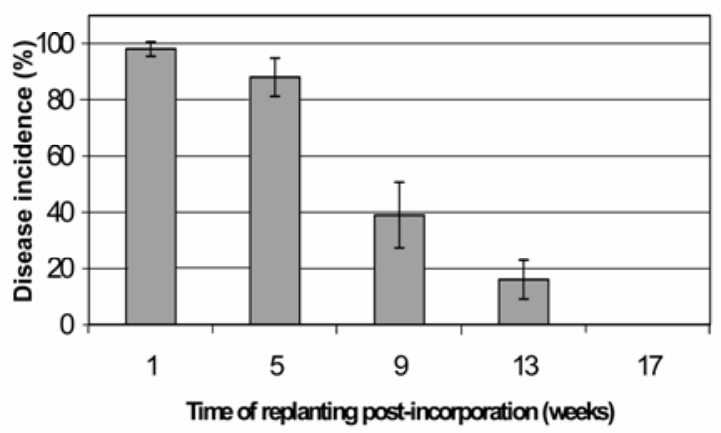

C Alisal 2000

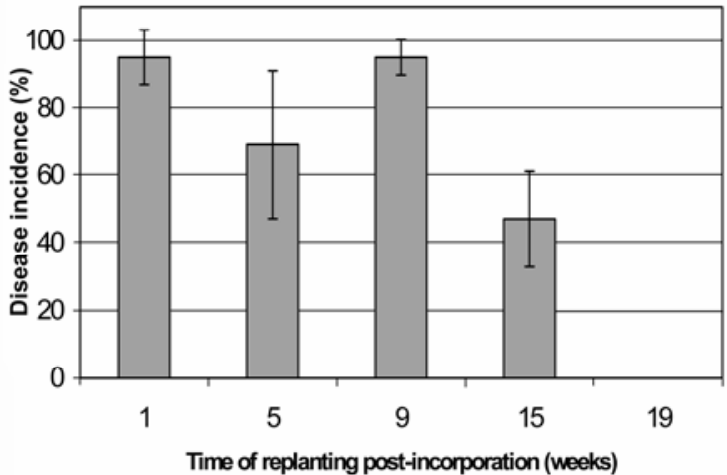

B Spence 1999

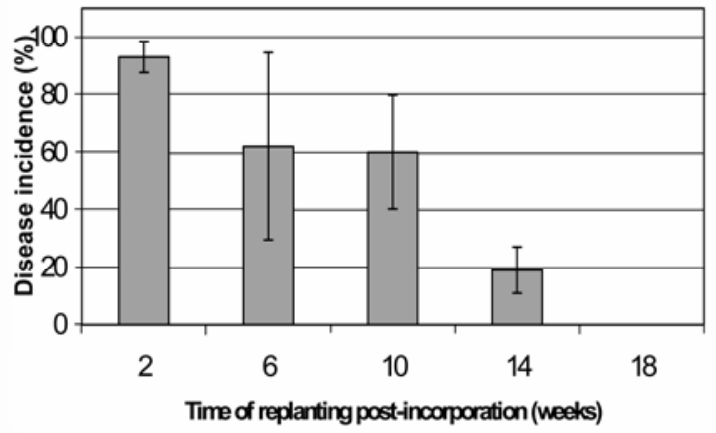

D Spence 2000

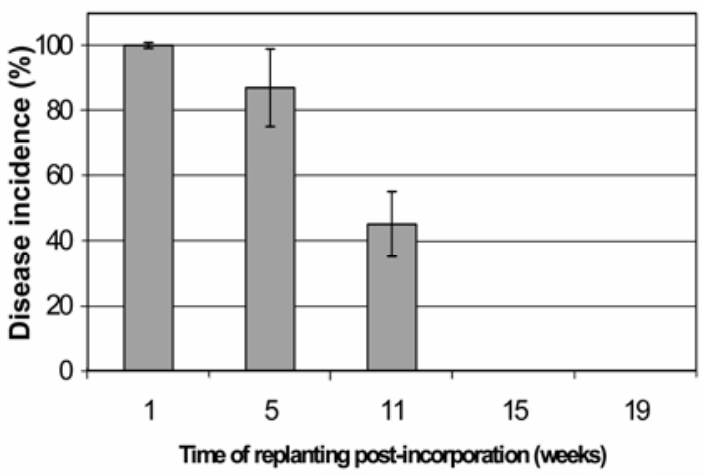

Fig. 1. Incidence of bacterial blight caused by Pseudomonas syringae pv. alisalensis on mature broccoli raab plants from various planting dates following incorporation of a diseased crop. After incorporating a severely diseased broccoli raab planting into the soil, seeds were planted at various dates postincorporation. Disease incidence was calculated as the number of plants with disease/total number of plants at maturity. Bars represent the mean of six replications, and their associated standard deviations are presented. Correlation coefficients for replant time and disease incidence were calculated, and all are significant at $P=0.0001\left(\mathbf{A},-0.98^{*} ; \mathbf{B},-0.97 * ; \mathbf{C}, 0.80^{*} ; \mathbf{D}, 0.96^{*}\right)$. 
residue. Soil was collected $0,7,14$, and 21 days after incorporation. Additional soil samples were periodically collected from replanted beds between 5 and 20 weeks after incorporation, concurrent with disease rating and plant harvest. Approximately $20 \mathrm{~g}$ of soil was collected from the top $15 \mathrm{~cm}$ of soil at nine locations (distributed along an $\mathrm{X}$ shaped pattern) within each replanted plot. The soil samples from each plot were mixed thoroughly. All samples were processed the day of collection. A 1-g subsample was suspended in $9 \mathrm{ml}$ of water, and aliquots of serial dilutions were spread on KBBCr. Individual fluorescent colonies were counted after incubation in the dark at room temperature (approximately $25^{\circ} \mathrm{C}$ ) for 3 to 5 days. The limit of detection varied between 1.75 and $2.75 \log$ (CFU/g) and depended upon the volume of the dilutions sampled. Samples with populations lower than the limit of detection were assigned a value equal to the limit of detection minus one under the assumption that the actual population was between this value and zero (9). Data were log transformed prior to analysis. Analysis of variance and separation of means were conducted on log-transformed data, and separation of means was performed using Tukey-Kramer HSD. Regression analysis and confirmation of normality of residuals were conducted using JMP (Version 4, SAS Institute).

Survival of bacteria in untreated or autoclaved soils. Field soil was collected from an area at the Spence field site that was free from crucifer cultivation for more than 3 years. The soil was stored at room temperature ( 22 to $24^{\circ} \mathrm{C}$ ) for up to 2 years. Immediately before using, the soil was sieved using a $1.7-\mathrm{mm}$ screen, and $2.0 \mathrm{~g}$ of dry soil was added to $25-\mathrm{mm}$ tubes. Half of the tubes were randomly selected and autoclaved at $121^{\circ} \mathrm{C}$ for $16 \mathrm{~min}$.

All tubes were inoculated with $0.2 \mathrm{ml}$ of a 12-h-old NB culture of strain BS91r, resulting in an initial concentration of approximately $1 \times 10^{8} \mathrm{CFU} / \mathrm{g}$ dry soil. In the 2 years preceding this experiment, the average soil temperature in the Salinas Valley was approximately $16^{\circ} \mathrm{C}$. Thus, the soil samples were incubated at $16^{\circ} \mathrm{C}$ in the dark for up to 15 days. The soil moisture (10\%) did not change over the course of the experiment (data not shown).

Population levels of $P$. syringae pv. alisalensis were measured by destructive sampling at $0,2,3,6,8,10,13$, and 15 days after inoculation. On each date, five replications of each treatment (autoclaved versus untreated soil) were evaluated. Ten milliliters of sterile distilled $\mathrm{H}_{2} \mathrm{O}$ was added to each tube, mixed with a vortex, and then the mixture was allowed to settle for 20 to $30 \mathrm{~min}$. Serial dilutions were then made from the aqueous portion of the samples, and aliquots were spread onto KBBCr. $P$. syringae pv. alisalensis was enumerated and data were analyzed as described for field soils. This experiment was conducted three times. Analysis of variance and separation of means were conducted on log-transformed data and by Tukey-Kramer HSD. Regression analysis and confirmation of normality of residuals were conducted using JMP (Version 4, SAS Institute).

As a control to ensure that autoclaving reduced populations of indigenous bacteria, populations of culturable bacteria and fluorescent pseudomonads were enumerated from autoclaved and nonautoclaved soils by spreading serial dilutions onto 0.10 strength TSA amended with cycloheximide $(80 \mu \mathrm{g} / \mathrm{ml})$ and $\mathrm{KB}$ amended with novobiocin $(45 \mu \mathrm{g} / \mathrm{ml})$, penicillin $\mathrm{G}$ (75 $\mu \mathrm{g} / \mathrm{ml}$ ), and cycloheximide (40), respectively. Additionally, myxobacterial populations were enumerated by heating dilutions to $50^{\circ} \mathrm{C}$ for $2 \mathrm{~h}$ followed by spreading onto CY-C10 agar plates (8). The plates were incubated for 3 to 5 days at room temperature $\left(25^{\circ} \mathrm{C}\right)$ prior to counting colonies.

Influence of soil populations on disease incidence. Greenhouse experiments were conducted to determine if there was a relationship between the population levels of $P$. syringae pv. alisalensis in soil and disease incidence on broccoli raab seedlings. Twenty-two grams of sifted SuperSoil potting mixture (Rod Mclellan Co., San Mateo, CA) was used to fill cells of a $13 / 4^{\prime} \times 1 \quad 1 / 2^{\prime}$-sized six-pack container. One pack containing six plants was one experimental unit and there were six replications per treatment. The soil in each cell was drenched with $22 \mathrm{ml}$ of 10 -fold dilutions of a $P$. syringae pv. alisalensis BS91r suspension or a water control. The inoculum was prepared as described above and the initial suspension was adjusted to approximately $1 \times 10^{9} \mathrm{CFU} / \mathrm{ml}$ spectrophotometrically. Tenfold serial dilutions, which resulted in populations ranging from approximately $1 \times 10^{1}$ to $1 \times 10^{9} \mathrm{CFU} / \mathrm{ml}$, were prepared for soil inoculations. Culturable populations were estimated for each inoculum concentration by dilution plating. After inoculating the soil, one broccoli raab seed was planted in each cell of the packs. The plants were incubated in a mist chamber in a greenhouse until 2 days after germination. The plants were then moved to a greenhouse bench and watered from the bottom until they developed true leaves (14 days after planting) and were evaluated. Disease was recorded for plants with characteristic bacterial blight symptoms on the petioles or first true leaves. For each replication, bacteria were isolated from a representative lesion. Fluorescent bacteria were selected on $\mathrm{KBBCr}$, and rep-PCR was used to confirm the identity of the pathogen. Disease incidence was calculated as the percentage of diseased plants in each six-pack. Regression analysis and confirmation of normality of residuals were conducting using
JMP. The experiment was conducted three times, and data from two representative experiments are presented.

\section{RESULTS}

Ability of inoculum from a previous crop to infest a new crop. Severe disease symptoms occurred in all initial plantings inoculated with either BS91 or BS91r. Disease incidence in all plots was at or close to $100 \%$. The fate of the pathogen was followed in plots inoculated with BS91r. In these plots, rifampicin-resistant fluorescent pseudomonads were isolated from all lesions taken from plants in replanted plots. All clones evaluated had repPCR patterns identical to that of $P$. syringae pv. alisalensis, indicating that disease in subsequent plantings was caused by the pathogens inducing the disease in the first planting. Additionally, for the initial two replanting dates, the number of bacteria recovered from lesions on the semiselective medium KBBC was similar to the numbers recovered on $\mathrm{KBBCr}$ (data not shown), indicating the BS91r was responsible for causing disease in the initial replantings. Mixtures of rifampicin-resistant and -nonresistant clones were isolated from lesions developing on plants with longer fallow times, indicating that nonresistant populations of the pathogen were beginning to move into the plantings initially inoculated with BS91r from alternative sources.

Influence of length of fallow on subsequent disease development. There was a general trend in all field data showing that the incidence of disease decreased as the length of fallow between plantings increased (Fig. 1). The Pearson correlation coefficients between the length of fallow and disease incidence were determined for all four experiments. In every case, there was a significant $(P=0.0001, n=60)$ inverse relationship between length of fallow and disease incidence. In addition, there were statistically significant decreases in disease at each sampling date corresponding to increasing length of fallow at the Alisal and Spence sites in 1999 and 2000 $(P=0.0001)$. Although there was a significant inverse correlation between disease incidence and length of fallow $(P=$ $0.0001)$ for the entire experiment conducted at Spence in 1999, disease incidence did not decline significantly between the second and third replanting (Fig. 1B). A similar result was obtained in 2000 at the Alisal site except that the disease incidence increased numerically from the second to the third replanting (Fig. 1C). For all experiments, diseased plants were not found in the final replanting, which were rated at maturity between 24 and 32 weeks after incorporation. For the last replanting plots, there were fallow periods ranging between 17 and 19 weeks after incorporation of the diseased crop. In control plantings where the pathogen was 
inoculated on seedlings after emergence, disease was seen in all but the last ( 1 or 2 ) plantings, indicating that the decline in disease incidence later in the season may have been due to changes in the environment (data not shown).

Bacterial survival in soil. At both field locations, culturable populations recovered from field soil declined over the 3-week sampling period (Fig. 2). Populations were recovered 15 days after incorporation at both sites $\left(1 \times 10^{4} \mathrm{CFU} / \mathrm{g}\right.$ of soil), but were under the limit of detection $\left(1 \times 10^{2}\right.$ $\mathrm{CFU} / \mathrm{g}$ ) after 21 days. In all experiments, populations at 0 and 7 days after incorporation were not significantly different, but populations at 21 days were significantly lower than populations at 0 and 7 days after incorporation $(P=0.05)$.

Autoclaving soil decreased the background microflora including total bacteria enumerated on a general minimal medium, fluorescent pseudomonads, and myxobacteria to below the level of detection in most cases (data not shown). Additionally, autoclaving field soil enabled $P$. syringae pv. alisalensis to maintain populations at introduced levels (Fig. 3). Populations of $P$. syringae pv. alisalensis remained above 1 $\times 10^{6} \mathrm{CFU} / \mathrm{g}$ in autoclaved soil throughout the 15 days of the experiment, whereas in untreated soil population levels on $\mathrm{KBBCr}$ dropped rapidly to below the level of detection (90 CFU/g soil) by 13 days after inoculation.

Influence of soil populations on disease incidence. There was a significant positive correlation between the population level of the pathogen used to inoculate the soil and disease incidence of seedlings at 14 and 21 days after planting $(P<0.0001)$. At the highest population tested, $2.7 \times 10^{9}$ $\mathrm{CFU} / \mathrm{ml}$, some plants did not become diseased, indicating that even with sufficient inoculum, plants may escape the disease. Bacterial leaf blight was not detected on broccoli raab seedlings when seeds were planted in soil saturated with $P$. syringae pv. alisalensis concentrations of $2.5 \times 10^{3}$ CFU/ml or less (Fig. 4).

\section{DISCUSSION}

Holdover inoculum of $P$. syringae pv. alisalensis from a blighted broccoli raab crop played a significant role in the development of disease on subsequent broccoli raab plantings. This was inferred from the demonstration that clones of the pathogen isolated from lesions on the subsequent planting were identical to that used to inoculate the initial planting. In particular, rifampicin-resistant clones of $P$. syringae pv. alisalensis identical to the initial inoculant were isolated from lesions on the leaves in subsequent crops. The implication of holdover inoculum was further strengthened by the following observations: (i) only rifampicin-resistant colonies were isolated from lesions on plants sown during initial plant back times; and (ii) all colonies analyzed from lesions in the subsequently diseased planting had rep-PCR fingerprint patterns identical to $P$. syringae pv. alisalensis.

Rifampicin resistance in bacteria is rare in the environment (45), making it a useful tool for tracking microorganisms in soil and on plants. For nearly 30 years, rifampicin resistance has been used to monitor movement and population dynamics of bacterial plant pathogens, including $P$. syringae, in the environment $(20,35,37,47)$. Relatively recently, rep-PCR has been used in molecular epidemiological studies of plant pathogens $(30,39)$. The specificity of the fingerprints obtained using this method is dependent upon the repetitive elements targeted by the primers used and the taxon being investigated. Using BOXA1R prim- ers, we detected measurable genetic variation among isolates of $P$. syringae pv. alisalensis. Two similar but distinct repPCR fingerprints exist for this pathogen. Strains isolated from broccoli and broccoli raab have identical fingerprints, while fingerprints of strains from arugula differ from these by only one band regardless of the geographic origin of the strain, although all of the organisms are pathogenic on reciprocal hosts (6). Although there is some variation among isolates of $P$. syringae pv. alisalensis, these rep-PCR fingerprints are unique to this pathogen and differ significantly from $P$. syringae $\mathrm{pv}$. maculicola, a crucifer pathogen, and other $P$. syringae tested (12).

These tools helped to demonstrate clearly that holdover inoculum caused

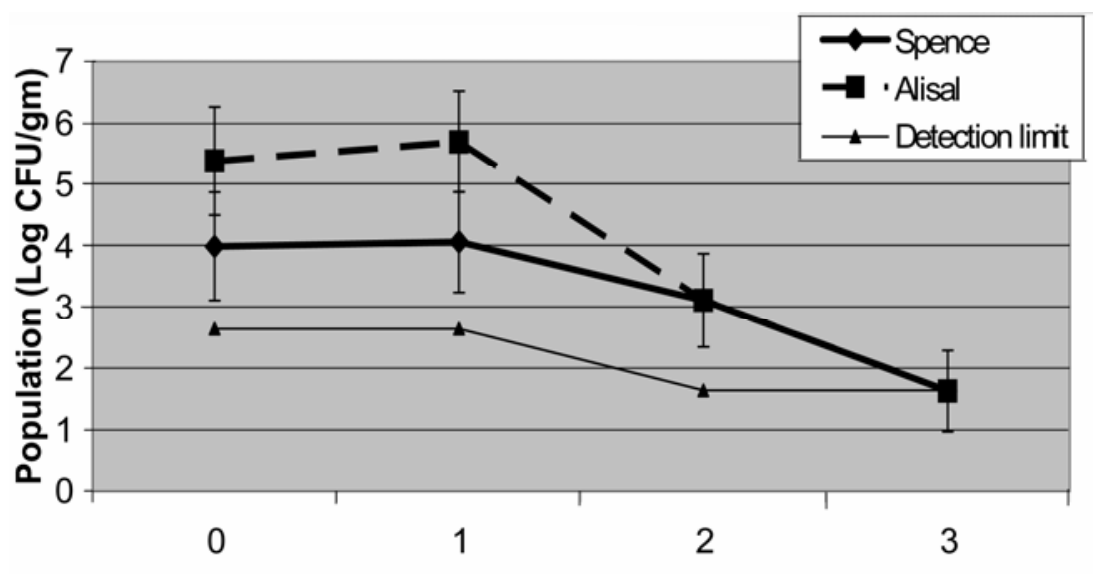

Time post-incorporation (weeks)

Fig. 2. Culturable populations of Pseudomonas syringae pv. alisalensis from soil sampled at various times after incorporation of a diseased broccoli raab crop. Fluorescent rifampicin-resistant colonies were periodically isolated on KBBC amended with rifampicin. Data points represent the mean of six replications, and their associated standard deviations are presented. Data points within experiments for which there is no overlap of standard deviation are significantly different at $P=0.05$ according to Tukey-Kramer HSD. Additionally, there was a negative correlation $(P \leq 0.0002)$ between populations in the soil and time after incorporation $\left(R^{2} \geq 0.50\right)$.

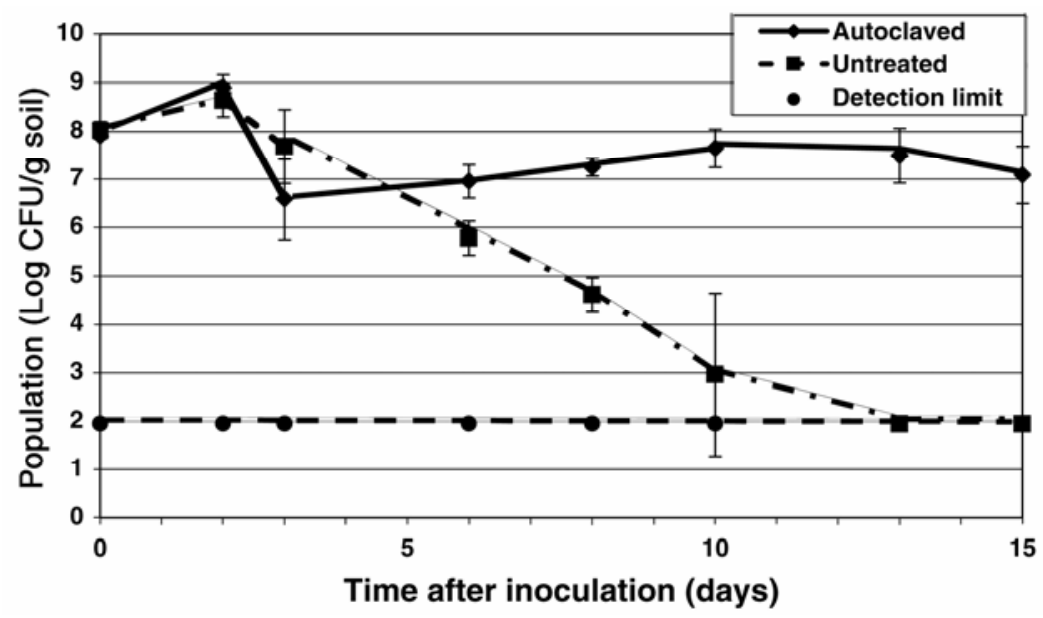

Fig. 3. Culturable populations of Pseudomonas syringae pv. alisalensis in autoclaved and untreated soil incubated at $16^{\circ} \mathrm{C}$. Soil was inoculated with the pathogen at approximately $1 \times 10^{8} \mathrm{CFU} / \mathrm{g}$ soil. Periodically, rifampicin-resistant colonies were enumerated on KBBC amended with rifampicin. Data points represent the mean of five replications, and their associated standard deviations are presented. Data points within experiments for which there is no overlap of standard deviation are significantly different at $P=0.05$ according to Tukey-Kramer HSD. 
disease in subsequent crop cycles, and even after 2 months of fallow, 40 to $90 \%$ of the plants grown in these plots were diseased. This does not appear to be unusual, since in some pathosystems holdover inoculum is responsible for initiating infections the spring after overwintering (20). the length of time increased from the time of incorporation of the diseased plant tissue. Significant disease reduction was seen when plantings were delayed to 3 to 4 months after planting. There are several potential explanations for the decrease in disease over time. Changes in disease incidence in the replanted broccoli raab plants may have resulted partially from changes in the environment, since disease incidence was measured over a 4- to 6-month period in plantings initiated over a 4- to 5-month period. Environmental conditions play a role in the development of bacterial speck of tomato caused by P. syringae pv. tomato (13). Specifically, changes in photoperiod and light intensity that occur over several months may influence bacterial disease expression $(36,41,44)$. Greater light intensities usually are more conducive than low intensities to disease development. In control plantings in a noninfested section of the field, differences were detected due to seasonal variability, but these did not account for all of the differences seen in replant plots (data not shown). The influence of seasonal variation on disease development from holdover inoculum needs to be tested using a different experimental approach.

Alternatively, declining populations of the pathogen may have contributed to the decline in disease throughout the season. Many bacterial plant pathogens, including some pathovars of $P$. syringae, are not believed to be able to survive for long in
However, disease incidence declined as

soil when not in association with plant debris (27). Population levels of pathogenic bacteria have been shown to drop rapidly to below the level of detection when plate counting is used as a detection method $(2,25)$. This can occur within 2 weeks in untreated dry soil and is consistent with our field and laboratory observations of $P$. syringae pv. alisalensis, although field samples consisted of both soil and plant debris.

More often, bacteria survive over long periods in plant debris (28), and it was surprising that the sampling method did not detect the populations soon after incorporation since the samples contained some fraction of debris. However, the sampling method may have significantly underestimated populations of the pathogen in debris by diluting the populations with soil infested at low levels. According to Barak et al. (1), the temperate climate of California's Salinas Valley may be conducive to short-term survival of bacterial pathogens in crop residues. They demonstrated that Xanthomonas campestris pv. vitians, the lettuce (Lactuca sativa) bacterial leaf spot pathogen, survived in lettuce residue in field soils for a few months. One of the research locations used by Barak et al. was also used in this study (Spence). Additionally, there are examples of $P$. syringae strains surviving in plant debris and serving as inoculum for subsequent crops. Pea crop residue served as an inoculum source of $P$. syringae pv. pisi for infection on field pea; this pathogen survived on buried pea trash for 29 weeks and surface trash for 78 weeks. Naturally infected pea trash caused a $25 \%$ reduction in yield due to bacterial blight (19). Research indicated that crop debris may play a role in over-wintering of populations of $P$. syringae pv. tomato (20). Likewise, $P$. syringae pv. maculicola survives in debris in the soil and does not

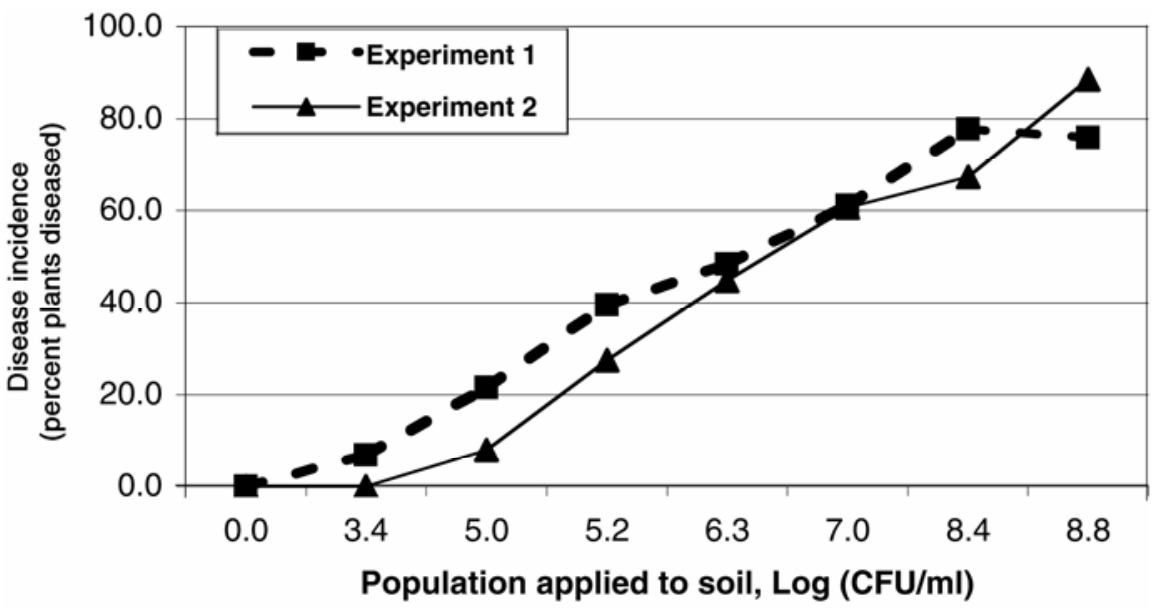

Fig. 4. Relationship between soil populations of Pseudomonas syringae pv. alisalensis and disease incidence in seedlings 14 days after planting. Prior to planting seed, bacteria were applied to soil at increasing concentrations. Disease incidence on seedlings was evaluated 2 weeks after planting. There were significant positive correlations $(P<0.0001)$ between populations in the soil and time after incorporation in all experiments at both 14 and 21 days after planting. Data from the 14-day evaluation time are presented $\left(R^{2}=0.69\right.$ and 0.76 for experiments 1 and 2 , respectively). survive long exposed directly to the soil (50). It may be that plant debris serves as the reservoir for holdover inoculum in the pathosystem explored here, because disease still occurred after the pathogen was no longer detected in our samples.

The rapid drop in population levels detected in soil may be a true representation of the population dynamics of $P$. syringae pv. alisalensis in soil or may be an artifact of the enumeration method used. For example, rifampicin masking or the lack of growth of resistant bacteria on antibioticcontaining media may underestimate the population levels of resistant bacteria $(32,34)$. This drawback may have significantly affected the ability to monitor populations but was not significant in identifying rifampicin-resistant clones from lesions in subsequent plantings. Alternatively, culture-dependant methods may not enumerate organisms that have entered into a viable but nonculturable state (VBNC). Organisms in this state appear to be respiring at some level but are no longer enumerated using standard culture techniques $(33,49)$. This phenomenon may play an important role in the ecology of $P$. syringae in dry and nutrient poor environments (48). Any of these potential shortcomings in the enumeration method used may partially explain why disease still occurred after we no longer detected the pathogen from field soil and debris.

Because field data did not allow inferences about the role of bacterial populations in the soil on subsequent disease development in the field, we conducted greenhouse experiments evaluating the influence of bacterial population levels in soil on subsequent disease development. Data from these greenhouse experiments support the hypothesis that the pathogen population in the planting medium is directly correlated with disease on developing plants. In these studies, there was a clear positive correlation between population levels of the pathogen in the soil and disease incidence on seedlings. This implies that a reduction in bacterial populations in the soil environment could result in a reduction in disease.

In general, $P$. syringae strains do not survive as long in nontreated soil as they do in pasteurized soil $(2,3,15,19,25)$. In the laboratory studies reported here, heat labile factors, probably biological in nature, may have played a role in the maintenance of the pathogen populations since population levels of $P$. syringae pv. alisalensis declined in natural soil but survived in high numbers in autoclaved soil. The poor survival of bacterial plant pathogens in soil is often attributed to inhibition by antagonistic microflora (43). We are currently evaluating myxobacteria that prey on bacteria, including foliar pathogens like $P$. syringae pv. alisalensis (4). We are evaluating predation in the soil with the goal of increasing the rate at which the pathogen popula- 
tion declines and shortening the length of fallow needed before replanting.

The data presented have important implications for disease management, in part due to our expanding knowledge about the wide host range of $P$. syringae pv. alisalensis in the Salinas Valley and other parts of the United States. In particular, these data have implications for crop choices and the length of fallow between a diseased field and subsequent susceptible crops. Specifically, our findings are pertinent and timely because there is pressure on the vegetable industry in the Salinas Valley to rapidly replant fields to obtain multiple crops each season. This can result occasionally in a second susceptible crop being planted within a few weeks of incorporation of diseased material into the field. Depending on the time of year and the length of fallow between plantings, the second plantings may be at high risk of becoming diseased. To reduce risk of bacterial blight on crucifers, we therefore recommend that crucifer crops not be planted back-to-back, or if such a repeat cropping cycle is used, that a sufficient delay is implemented prior to planting the second crop. As with all bacterial diseases of vegetable crops, the use of overhead sprinkler irrigation should be avoided.

\section{ACKNOWLEDGMENTS}

Special thanks to Sharon Benzen, Polly Goldman, Diana Henderson, Thi Duong, Zachary Knapp, Nicole Morris, Freddy Rosales, Feliciana Orozco, and E. J. Rowland for technical support on this project. We appreciate the helpful comments from Y. Zhao and E. Little about this manuscript. This project was partially funded by D'Arrigo Bros. Company.

\section{LITERATURE CITED}

1. Barak, J. D., Koike, S. T., and Gilbertson, R. L. 2001. Role of crop debris and weeds in the epidemiology of bacterial leaf spot of lettuce in California. Plant Dis. 85:169-178.

2. Bashan, Y., Diab, S., and Okon, Y. 1982. Survival of Xanthomonas campestris pv. vesicatoria in pepper seeds and roots in symptomless and dry leaves in non-host plants and in the soil. Plant Soil 68:161-170.

3. Bull, C. T. 1987 . Wheat root colonization by disease-suppressive or nonsuppressive bacteria and the effect of population size on severity of take-all caused by Gaeumannomyces graminis var. tritici. M.S. thesis. Washington State University, Pullman.

4. Bull, C. T. 2003. Myxobacterial predation of plant pathogenic and plant associated bacteria. (Abstr.) Phytopathology 93:S12.

5. Bull, C. T., Goldman, P., and Koike, S. T. 2004. Bacterial blight on arugula, a new disease caused by Pseudomonas syringae pv. alisalensis in California. Plant Dis. 88:1384.

6. Bull, C. T., Goldman, P. H., Morris, N. C., Koike, S. T., and Kobayashi, D. Y. 2004. Expanded host and geographic range of Pseudomonas syringae pv. alisalensis. (Abstr.) Phytopathology 94:S12.

7. Bull, C. T., Goldman, P. H., Smith, R. F., and Koike, S. T. 2004. Pseudomonas syringae pv. alisalensis and Pseudomonas syringae pv. maculicola cause disease on crucifers used in cover crop mixtures. (Abstr.) Phytopathology 94:S150.

8. Bull, C. T., Shetty, K. G., and Subbarao, K. V.
2002. Interactions between myxobacteria, plant pathogenic fungi, and biocontrol agents. Plant Dis. 86:889-896.

9. Bull, C. T., Stack, J. P., and Smilanick, J. L. 1997. Pseudomonas syringae strains ESC-10 and ESC-11 survive in wounds on citrus and control green and blue molds of citrus. Biol. Control 8:81-88.

10. Cintas, N. A., Koike, S. T., and Bull, C. T. 2000. Rappini bacterial blight declines with delayed replanting in the Salinas Valley of California. (Abstr.) Phytopathology 90:S15.

11. Cintas, N. A., Koike, S. T., and Bull, C. T. 2001. Emerging bacterial pathogens of crucifers in the Salinas Valley of California. Pages 272-274 in: Plant Pathogenic Bacteria. S. H. De Boer, ed. Kluwer Academic Publishers, Dordrecht, The Netherlands.

12. Cintas, N. A., Koike, S. T., and Bull, C. T. 2002. A new pathovar, Pseudomonas syringae pv. alisalensis pv. nov., proposed for the causal agent of bacterial blight of broccoli and broccoli raab. Plant Dis. 86:992-998.

13. Cuppels, D. A., and Elmhirst, J. 1999. Disease development and changes in the natural Pseudomonas syringae pv. tomato populations on field tomato plants. Plant Dis. 83:759-764.

14. Daft, G. C., and Leben, C. 1973. Bacterial blight of soybeans: Field-overwintered Pseudomonas glycinea as possible primary inoculum. Plant Dis. Rep. 57:156-157.

15. Devash, Y., Okon, Y., and Henis, Y. 1980. Survival of Pseudomonas tomato in soil and seeds. Phytopathol. Z. 99:175-185.

16. Fett, W. F. 1979. Survival of Pseudomonas glycinea and Xanthomonas phaseoli var. sojensis in leaf debris and soybean seed in Brazil. Plant Dis. Rep. 63:79-83.

17. Gardan, L., Shafik, H., Belouin, S., Broch, R., Grimont, F., and Grimont, P. A. D. 1999. DNA relatedness among the pathovars of Pseudomonas syringae and description of Pseudomonas tremae sp. nov. and Pseudomonas cannabina sp. nov. (ex Sutic and Dowson 1959). Int. J. Syst. Bact. 49:469-478.

18. Hoitink, H. A. J., Hagedorn, D. J., and McCoy, E. 1968. Survival, transmission, and taxonomy of Pseudomonas syringae van Hall, the causal organism of bacterial brown spot of bean (Phaseolus vulgaris L.). Can. J. Microbiol. 14:437-441.

19. Hollaway, G. J., and Bretag, T. W. 1997. Survival of Pseudomonas syringae pv. pisi in soil and on pea trash and their importance as a source of inoculum for a following field pea crop. Aust. J. Exp. Agric. 37:369-375.

20. Jardine, D. J., Stephens, C. T., and Fulbright, D. W. 1988. Potential sources of initial inoculum for bacterial speck in early planted tomato crops in Michigan: Debris and volunteers from previous crops. Plant Dis. 72:246-249.

21. Kennedy, B. W. 1969. Detection and distribution of Pseudomonas glycinea in soybean. Phytopathology 59:1618-1619.

22. King, E. O., Ward, M. K., and Raney, D. E. 1954. Two simple media for the demonstration of pyocyanin and fluorescin. J. Lab. Clin. Med. 44:301-307.

23. Koike, S. T., Cintas, N. A., and Bull, C. T. 2000. Bacterial blight, a new disease of broccoli caused by Pseudomonas syringae in California. Plant Dis. 84:370.

24. Koike, S. T., Henderson, D. M., Azad, H. R., Cooksey, D. A., and Little, E. L. 1998. Bacterial blight of broccoli raab: A new disease caused by a pathovar of Pseudomonas syringae. Plant Dis. 82:727-731.

25. Kritzman, G., and Zutra, D. 1983. Survival of Pseudomonas syringae pv. lachrymans in soil, plant debris, and the rhizosphere of non-host plants. Phytoparasitica 11:99-108.

26. Lauritzen, E. 2005. Monterey County 2004 Crop Report. Agricultural Commissioner's Office, Salinas, CA
27. Leben, C. 1974. Survival of plant pathogenic bacteria. Spec. Circ. 100. Ohio Agricultural Research and Development Center, Wooster.

28. Leben, C. 1981. How plant-pathogenic bacteria survive. Plant Dis. 65:633-637.

29. Legard, D. E., and Hunter, J. E. 1990. Pathogenicity on bean of Pseudomonas syringae pv. syringae recovered from the phylloplane of weeds and from bean crop residue. Phytopathology 80:938-942.

30. Louws, F. J., Rademaker, J. L. W., and de Bruijn, F. J. 1999. The three Ds of PCR-based genomic analysis of phytobacteria: Diversity, detection, and disease diagnosis. Annu. Rev. Phytopathol. 37:81-125.

31. Mabagala, R. B., and Saettler, A. W. 1992. Races and survival of Pseudomonas syringae pv. phaseolicola in northern Tanzania. Plant Dis. 76:678-682.

32. Mahaffee, W. F., Bauske, E. M., van Vuurde, J. W. L., van der Wolf, J. M., van den Brink, M., and Kloepper, J. W. 1997. Comparative analysis of antibiotic resistance, immunofluorescent colony staining, and a transgenic marker (bioluminescence) for monitoring the environmental fate of a rhizobacterium. Appl. Environ. Microbiol. 63:1617-1622.

33. McDougald, D., Rice, S. A., Weichart, D., and Kjelleberg, S. 1998. Nonculturability: Adaptation or debilitation? FEMS Microbiol. Ecol. 25:1-9.

34. McInroy, J. A., Musson, G., Wei, G., and Kloepper, J. W. 1996. Masking of antibiotic resistance upon recovery of endophytic bacteria. Plant Soil 186:213-218.

35. Milus, E. A., and Mirlohi, A. F. 1995. Survival of Xanthomonas campestris pv. translucens between successive wheat crops in Arkansas. Plant Dis. 79:263-265.

36. Mohamed, M. F., and Coyne, D. P. 1995. Photoperiod sometimes influences common bacterial blight disease of common beans. HortScience 30:551-553.

37. Park, E. W., and Lim, S. M. 1985. Overwintering of Pseudomonas syringae pv. glycinea in the field. Phytopathology 75:520-524.

38. Pham, V. D., Shebelut, C. W., Diodati, M. E., Bull, C. T., and Singer, M. 2005. Mutations affecting predation ability of the soil bacterium Myxococcus xanthus. Microbiology 151:18651874

39. Rademaker, J. L. W., Louws, F. J., and de Bruijn, F. J. 1998. Characterization of the diversity of ecologically important microbes by rep-PCR genomic fingerprinting. Mol. Microbiol. Ecol. Man. 3.4.3:1-27.

40. Sands, D. C., and Rovira, A. D. 1970. Isolation of fluorescent pseudomonads with a selective medium. Appl. Microbiol. 20:513-514

41. Santana, E. A., Coyne, D. P., Beaver, J. S., and Zaiter, H. Z. 1993. Effect of photoperiod and temperature on common blight disease of common beans (Phaseolus vulgaris L.). Euphytica 66:211-216.

42. Schaad, N. W., Jones, J. B., and Chun, W., eds. 2001. Laboratory Guide for Identification of Plant Pathogenic Bacteria. 3rd ed. American Phytopathological Society, St. Paul, MN.

43. Schuster, M. L., and Coyne, D. P. 1974. Survival mechanisms of phytopathogenic bacteria. Annu. Rev. Phytopathol. 12:199-221.

44. Smith, M. A., and Kennedy, B. W. 1970. Effect of light on reactions of soybean to Pseudomonas glycinea. Phytopathology 60:723-725.

45. Supkoff, D., Opgenorth, D., Lai, C., Segawa, R., and Koehler, D. 1987. Monitoring for genetically engineered Pseudomonas species in Monterey County. Biological Control Services Program, California Department of Food and Agriculture, Sacramento. Publ. EH 87-03.

46. Versalovic, J., Schneider, M., de Bruijn, F. J., and Lupski, J. R. 1994. Genomic fingerprinting of bacteria using repetitive sequence-based 
polymerase chain reaction. Methods Mol. Cell. Biol. 5:25-40.

47. Weller, D. M., and Saettler, A. W. 1978. Rifampin-resistant Xanthomonas phaseoli var. fuscans and Xanthomonas phaseoli: Tools for field study of bean blight bacteria. Phytopathology 68:778-781.
48. Wilson, M., and Lindow, S. E. 1992. Relationship of total viable and culturable cells in epiphytic populations of Pseudomonas syringae. Appl. Environ. Microbiol. 58:3908-3913.

49. Xu, H.-S., Roberts, N., Singleton, F. L., Attwell, R. W., Grimes, D. J., and Colwell, R. R. 1982. Survival and viability of nonculturable
Escherichia coli and Vibrio cholerae in the estuarine and marine environment. Microbiol. Ecol. 8:313-323.

50. Zhao, Y., Damicone, J. P., and Bender, C. L. 2002. Detection, survival, and sources of inoculum for bacterial diseases of leafy crucifers in Oklahoma. Plant Dis. 86:883-888. 